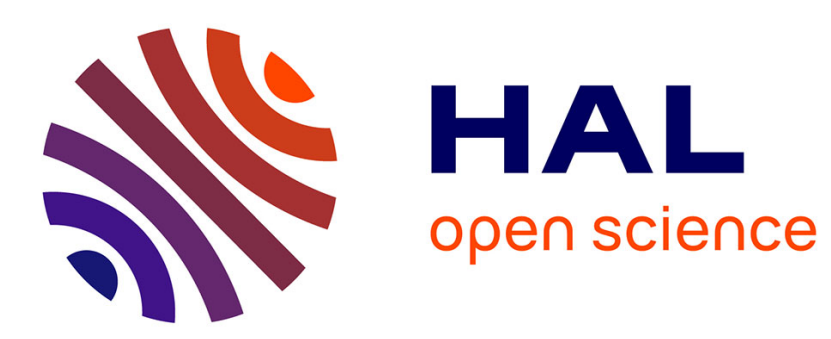

\title{
Regenerating mature Aleppo pine stands in fire-free conditions: Site preparation treatments matter
}

\author{
B. Prévosto, L. Amandier, T. Quesney, G. de Boisgelin, C. Ripert
}

\section{To cite this version:}

B. Prévosto, L. Amandier, T. Quesney, G. de Boisgelin, C. Ripert. Regenerating mature Aleppo pine stands in fire-free conditions: Site preparation treatments matter. Forest Ecology and Management, 2012, 282, p. 70 - p. 77 . 10.1016/j.foreco.2012.06.043 . hal-00777028

\section{HAL Id: hal-00777028 \\ https://hal.science/hal-00777028}

Submitted on 16 Jan 2013

HAL is a multi-disciplinary open access archive for the deposit and dissemination of scientific research documents, whether they are published or not. The documents may come from teaching and research institutions in France or abroad, or from public or private research centers.
L'archive ouverte pluridisciplinaire HAL, est destinée au dépôt et à la diffusion de documents scientifiques de niveau recherche, publiés ou non, émanant des établissements d'enseignement et de recherche français ou étrangers, des laboratoires publics ou privés. 
Author-produced version of the article published in Forest Ecology and Management, 2012, 282, 70-77.

Original publication available at http://www.sciencedirect.com/

doi : 10.1016/j.foreco.2012.06.043

1 Regenerating mature Aleppo pine stands in fire-free conditions: site preparation

\section{2 treatments matter}

3

$4 \underline{\text { Authors }}$

5 Bernard Prévosto ${ }^{(1)}$, Louis Amandier ${ }^{(2)}$, Thierry Quesney ${ }^{(3)}$, Gautier de Boisgelin ${ }^{(4)}$, Christian

6 Ripert $^{(1)}$

7

$8 \quad$ Address

9 (1) Irstea, Ecosystèmes méditerranéens et risques, 3275 Route Cézanne, CS 40061, F-13612

10 Aix-en-Provence cedex 5.

11 (2) CRPF, 7 Impasse Richard-Digne, F-13004 Marseille

12 (3) ONF, 1175 chemin du Lavarin, F-84000 Avignon

13 (4) ONF, Unité Territoriale de Vigneulles, 20 rue du Général de Gaulle, F-55210 Heudicourt-

14 sous-les-Côtes

15

16

17 Corresponding author: Bernard Prévosto

18 Tel: (33) $442669925 \quad$ Fax: (33) 442669910

19 e-mail: bernard.prevosto@irstea.fr 
Author-produced version of the article published in Forest Ecology and Management, 2012, 282, 70-77. Original publication available at http://www.sciencedirect.com/

doi : 10.1016/j.foreco.2012.06.043

\section{Abstract}

Aleppo pine is the most widespread pine species around the Mediterranean Basin. Its post-fire recruitment has been studied in depth, but regeneration of mature stands in fire-free conditions has received considerably less attention. This study examines the impact of different site preparation treatments on pine recruitment using three experimental mature stands along a gradient of site fertility in southeastern France. The stands were partially felled and subjected to the following treatments replicated four times on each site: mechanical chopping (all sites), chopping followed by single soil scarification (all sites) or double scarification ( 2 sites), controlled fire of low intensity ( 2 sites) or of high intensity (1 site) and control (all sites). In addition, the influence of slash, either left on the soil or removed before treatments, was tested for the single scarification treatment on two of the sites. Pine regeneration was counted and soil cover conditions described at different time intervals: 1 to 6 years after the end of the treatments for two sites and 1 to 16 years for one site. Seedling dimensions were determined during the last count. Mean seedling densities after 6-9 years (0.57-1.06 pines $\left./ \mathrm{m}^{2}\right)$ were comparable to those found in post-fire conditions, although with a narrower range. Pine density was negligible in the control, while chopping followed by a single soil scarification emerged as the most favourable treatment tested in the three sites on seedling density (0.74-1.54 pines $/ \mathrm{m}^{2}$ after 6-9 years) and seedling growth. For this treatment, the amount of slash had a contrasting influence on pine density according to site conditions. Double scarification did not affect pine density. Controlled high intensity fire, due to slash presence, was very favourable for pine regeneration $\left(2.35\right.$ pines $\left./ \mathrm{m}^{2}\right)$, although this treatment was only tested at one site. Lastly, we found low pine densities in the chopping and lowintensity controlled fire treatments $\left(0.20\right.$ to 0.56 pines $\left./ \mathrm{m}^{2}\right)$. Variation in herb cover was a major factor influencing pine recruitment. This study emphasises the need for adapted site preparation treatments to regenerate mature pine stands in southern Europe.

Key-words: Pinus halepensis, Mechanical treatment, Soil scarification, Controlled fire Soil cover conditions 
Author-produced version of the article published in Forest Ecology and Management, 2012, 282, 70-77.

Original publication available at http://www.sciencedirect.com/

doi : 10.1016/j.foreco.2012.06.043

\section{Introduction}

Plant recruitment is a key phase in plant population and community dynamics (Nathan and Ne'eman 2004), particularly in forest ecosystems, and foresters have devoted much effort to obtaining natural regeneration in ageing stands. However, regeneration of mature stands is challenging in the Mediterranean forests due essentially to limitations of seed and seedling establishment (e.g. Acácio et al., 2007; Mendoza et al. 2009; Smit et al., 2009), driven mainly by abiotic constraints such as drought (Castro et al. 2004), but also by high pressure from herbivores (Baraza et al. 2006) and sometimes inappropriate management techniques (Pulido et al. 2001).

In this study we examined the influence of different types of silvicultural treatments on Aleppo pine (Pinus halepensis) recruitment in various environmental conditions. $P$. halepensis (subsp. halepensis and brutia) is the most widespread coniferous species in the Mediterranean area, covering some 6.8 million hectares in the Mediterranean Basin (Barbéro et al., 1998). This pine exhibits a dual life history strategy characterized by its efficiency in exploiting new establishment opportunities generated by various disturbances in the absence or in the presence of fire (Ne'eman et al., 2004). Its capacity to colonise disturbed sites in firefree conditions is illustrated by the fast expansion of this species after land abandonment in southern France - from to 135000 to 250000 ha in less than 5 decades - and its ability to invade unburned disturbed areas in the southern hemisphere (Richardson, 2000). After a fire, recruitment of Aleppo pine, like other post-fire regenerating serotinous pines, is generally profuse though variable (Pausas et al., 2004a) and has been studied in depth (e.g. Trabaud et al., 1985, Daskalakou and Thanos 1996, Arianoutsou and Ne'eman 2000). In contrast, in the absence of fire, seedlings rarely establish beneath pine canopy and various explanations have been suggested such as light limitation, seed predation, needle layer effect (Arianoutsou and Ne'eman, 2000, Nathan and Ne'eman, 2004). Some studies performed on Pinus pinaster, another European Mediterranean pine with similar ecological traits, also showed the importance of percentage of litter cover on natural regeneration (Rodríguez-García et al., 2010) as well as the influence of coarse woody debris on post-fire recruitment (Castro et al., 2011). As no clear single key factor has been put forward to explain lack of regeneration of Aleppo pine in fire-free conditions, recruitment has been depicted as fairly unpredictable (Nathan and Ne'eman, 2004). In the course of succession in mesic or sub-humid areas, Aleppo pine is progressively replaced by hardwood species, mostly oaks such as Quercus ilex and Quercus pubescens, leading first to mixed stands and then to pure oak stands (Barbéro et 
Author-produced version of the article published in Forest Ecology and Management, 2012, 282, 70-77. Original publication available at http://www.sciencedirect.com/

doi : 10.1016/j.foreco.2012.06.043

al., 1998; Zavala et al., 2000). Therefore, in the absence of external disturbances, elimination of the Aleppo pine is likely to occur over the long term. However, maintaining Aleppo pine, in pure or mixed stands, is of importance for forest managers for both economic and ecological reasons. In productive areas with low fire risk, managers can target forest production by favouring pines, whereas in more fire-prone landscapes, pines and hardwood species (especially oaks) can be combined to take advantage of the faster growth of pines and the high resprouting capacity of oaks for fire resilience (Pausas et al., 2004b).

Like other pine species, regeneration of Aleppo pine is challenging in fire-free conditions and previous studies in natural coniferous mature stands of the temperate and boreal zones have shown that successful recruitment, early growth and survival can be strongly influenced by soil preparation and ground vegetation control treatments (e.g. see reviews by Balandier et al., 2006 and Wiensczyk et al., 2011). However, experiments testing impacts of such treatments in coniferous Mediterranean stands are scant (Prévosto and Ripert, 2008), even though silvicultural treatments may gain importance in the future for ensuring regeneration under climatic changes (Scarascia-Mugnozza et al., 2000; Spiecker, 2003).

In a previous field experiment, we showed that adapted site preparation treatments could have positive effects on pine regeneration over a short period after treatment application (Prévosto and Ripert, 2008). In this study, we sought to determine whether these first results held over a longer period of observation, and how variations in soil and climatic site conditions could influence seedling establishment, by integrating the results of two other field experimental sites. More specifically, our objectives were (i) to determine the impacts of vegetation and soil treatments on pine regeneration including emergence, survival and growth and (ii) to explain how these treatments determined soil cover conditions, which in turn influence pine recruitment. 
Author-produced version of the article published in Forest Ecology and Management, 2012, 282, 70-77.

Original publication available at http://www.sciencedirect.com/

doi : 10.1016/j.foreco.2012.06.043

\section{Materials and Methods}

\section{$\underline{\text { Site description }}$}

Three experimental sites located in southern France (Fig. 1) were selected along a gradient of soil fertility. The first and least productive site (Barbentane) is located on a gentle northfacing slope (altitude $105 \mathrm{~m}$ ) and has a meso-Mediterranean climate characterised by a dry, hot summer. Mean annual rainfall, computed over the period 1961-96, is $673 \mathrm{~mm}$ and the mean annual temperature is $14^{\circ} \mathrm{C}$ (Table 1). Soils are shallow calcareous, 10 to $20 \mathrm{~cm}$ deep, with a heavy stone load. The vegetation is dominated by a mature 90-100-year-old Aleppo pine forest (dominant height $12 \mathrm{~m}$ ) with a weakly developed shrub layer composed of Buxus sempervirens, Quercus ilex and Quercus coccifera. Brachypodium retusum is the most abundant species in the herbaceous layer.

\section{Figure 1}

128 The second site (Saint-Cannat, altitude $245 \mathrm{~m}$ ) lays on a flat area with a climate comparable to that of the first site: mean rainfall $620 \mathrm{~mm}$ and mean temperature $13.3{ }^{\circ} \mathrm{C}$. Soils are also

130 calcareous but deeper $(30 \mathrm{~cm})$ than in the first site and the limestone bedrock is more

131 fractured. These features, plus the fact that the area had been cultivated in the past, gives a

132 higher soil fertility than in Barbentane. The vegetation is composed of a 60-90-year-old 133 Aleppo pine tree layer (dominant height $15 \mathrm{~m}$ ), a developed shrub layer dominated by $134 Q$. coccifera and secondarily by Ulex parviflorus and Phillyrea angustifolia and a sparse 135 herbaceous layer.

136 The third site (Vaison-la-Romaine, hereafter Vaison, altitude 300m) is located on a gentle 137 northeast-facing slope further north than the two previous sites. The climate is wetter (mean 138 rainfall $761 \mathrm{~mm}$ ) and colder (mean temperature $\left.12.3^{\circ} \mathrm{C}\right)$. Soils are also deeper $(30-50 \mathrm{~cm})$, the

139 bedrock being composed of a micritic limestone. A mature 70-90-year-old Aleppo pine stand

140 (dominant height $16 \mathrm{~m}$ ) forms the upper tree layer, the subcanopy layer was well developed 141 and dominated by $Q$. pubescens and $Q$. ilex, and the herbaceous layer was composed mainly 142 of Brachypodium phoenicoides.

\section{Table 1}


Author-produced version of the article published in Forest Ecology and Management, 2012, 282, 70-77.

Original publication available at http://www.sciencedirect.com/

doi : 10.1016/j.foreco.2012.06.043

148 The three sites were all partially felled (regeneration cut) before treatment application during winter 2004-05 for Barbentane, winter 2002-03 for Vaison and winter 1990-91 for Saint-

150 Cannat (Table 1). The basal areas remaining after the cuts were respectively 12, 10 and $1519.5 \mathrm{~m}^{2} / \mathrm{ha}$ for Barbentane, Saint-Cannat and Vaison. Timber was removed in all sites, but 152 logging slash, mainly composed of tree canopy branches, were either left on the ground

153 (noted hereafter_S1) or removed (noted_S0) depending on sites and treatments (see below).

\section{$\underline{\text { Barbentane }}$}

156 Treatments were applied during winter and early spring 2005. A complete description of all

157 the treatments applied in this site is available in Prévosto and Ripert (2008). We recall below 158 the main characteristics of the seven treatments used in this study. They consisted in (Table 159 2):

(i) Ground vegetation chopping: this mechanical treatment reduces all branches, shrubs

(ii) Chopping followed by scarification of the soil in one direction in the presence of slash (SCA_S1),

(iii) Chopping followed by scarification of the soil in one direction with slash removed

(iv) Chopping followed by scarification in two perpendicular directions with slash left (SCA2_S1),

(v) Controlled intense fire in the presence of slash, leaving only ashes on the soil (FIRE_S1),

172 (vi) Controlled fire of low intensity without slash, ground vegetation and litter being only partially burned (FIRE_S0),

Treatments were applied on $200 \mathrm{~m}^{2}$ plots and replicated four times using four $2800 \mathrm{~m}^{2}$ blocks (one block included all the treatments).

178 Saint-Cannat

179 Four treatments were applied in 1995 and consisted of: 
181 (i) Chopping with slash (CHOP_S1),

182 (ii) Chopping with slash followed by scarification (SCA1_S1),

183 (iii) Low-intensity controlled fire (FIRE_S0),

184 (iv) Control (CONT).

186 Treatments were applied on $200 \mathrm{~m}^{2}$ plots and replicated four times using four $1000 \mathrm{~m}^{2}$ blocks

187 (one block included all the treatments).

$\underline{\text { Vaison }}$

Five treatments were applied during winter 2004-05:

192 (i) Chopping with slash (CHOP_S1)

193 (ii) Chopping without slash followed by soil scarification in one direction (SCA1_S0)

194 (iii) Chopping with slash followed by soil scarification in one direction (SCA1_S1)

195 (iv) Chopping with slash followed by soil scarification in two perpendicular directions (SCA2_S1),

(v) Control (CONT).

199 Treatments were applied on plots from 600 to $2000 \mathrm{~m}^{2}$ (mean $1120 \mathrm{~m}^{2}$ ) and replicated four times, except for the control, which was replicated twice, using four blocks (one block included all the treatments) ranging from 4000 to $6900 \mathrm{~m}^{2}$.

Table 2

204

\section{$\underline{\text { Sampling and measurements }}$}

In all three sites, sampling was done in each plot using $1 \mathrm{~m}^{2}$ subplots regularly installed along 2 to 5 transects. In Barbentane, 15 subplots were used per plot, except in the control (10 subplots), resulting in a total of 400 subplots for the whole experiment. In Saint-Cannat, 36 subplots were used per plot (total 576 subplots) and Vaison 20 to 21 subplots per plot (total

211369 subplots).

212 In each subplot, live pine seedlings were counted and soil surface description was carried out

213 at the end of the growing season at years 1 to 6 after the end of the treatments in Barbentane,

214 at years 1, 3, 9 and 16 in Saint-Cannat and at years 1, 2, 3 and 6 in Vaison. 
Author-produced version of the article published in Forest Ecology and Management, 2012, 282, 70-77.

Original publication available at http://www.sciencedirect.com/

doi : 10.1016/j.foreco.2012.06.043

215 Soil surface description consisted in visually estimating the cover in bare soil, grass, shrub,

216 and litter using an abundance dominance coefficient derived from the Braun-Blanquet

217 method: 1 presence, $2<5 \%, 3=$ [5-25\%[, $4=$ [25-50\%[, $5=$ [50-75\%[, $6=$ [75-100\%]. For

218 subsequent computations the centre of each class was used. In each site, during the last count

219 we measured seedling height and stem diameter of all seedlings older than 1 year.

220

$221 \quad$ Data analysis

223 Pine density did not meet ANOVA conditions even after mathematical transformations, as our data sets exhibited over-dispersion and an excessive number of zeros. Previous analyses (not shown) demonstrated that density was adequately modelled by a negative binomial law. We therefore ran generalised linear models (GLM) for each site using a negative binomial relationships to test the effects of treatment used a categorical variable, time and soil cover conditions used as quantitative variables (procedure 'glm.nb' of the 'MASS' package, R software). If treatment effect was found significant, we then used non-parametric multiple comparisons following the method proposed by Siegel and Castellan (1988) to detect significant differences $(P<0.05)$ among the treatments. To analyse the influence of the treatments and time on soil covers in bare soil, herb and shrub we also produced GLM models

233 (procedure 'glm' of the 'car' package, R software). Height data were log-transformed to meet 234 the conditions of normality and homogeneity of variances. Classical ANOVAs followed by 235 Tukey post hoc tests were then performed to detect significant differences $(P<0.05)$ among 236 the treatments. 
Author-produced version of the article published in Forest Ecology and Management, 2012, 282, 70-77.

Original publication available at http://www.sciencedirect.com/

doi : 10.1016/j.foreco.2012.06.043

\section{Results}

Effects of treatments and soil surface conditions on pine density

241 Pine density varied with time and was significantly influenced by the treatments in all sites

\section{2 (Table 3).}

243 Table 3

244 Pine density peaked at 2-3 years for all sites (Fig.2) and then moderately decreased for

245 Barbentane and Vaison. By contrast, density fell sharply in Saint-Cannat from 2.10 pines $/ \mathrm{m}^{2}$ at 3 years to 0.58 pines $/ \mathrm{m}^{2}$ at 9 years (all treatments together), due to an infestation by the fungal plant pathogen Crumenolopsis sororia, which killed a large number of seedlings.

Figure 2

In all three sites, chopping followed by a single scarification emerged as the most favourable treatment. It was noteworthy that presence or absence slash did matter; pine density was higher with slash in Barbentane than without slash, whereas the reverse was true in Vaison.

254 Surprisingly, chopping followed by a double scarification, tested in Vaison and Barbentane, led to lower pine densities than the previous treatment. It was also largely less favourable to regeneration than the high-intensity controlled fire treatment (FIRE_S1). This latter treatment proved to be as efficient as the single scarification treatment, although it was tested at only one site. By contrast, lower pine densities were recorded after low-intensity fire treatment (FIRE_S0, Barbentane and Saint-Cannat) and after the chopping treatment (all sites). Lastly, the absence of any interventions in the control prevented seedlings becoming established or only at a very low density.

262 Herb cover emerged as the most significant soil surface descriptor influencing pine density in 263 all sites whereas shrub an soil cover had a contrasting and less significant influence (Table 3 ).

264 Herb cover, mainly composed of grass species in particular Brachypodium retusum in

265 Barbentane and Saint-Cannat and Brachypodium phoenicoides in Vaison, exerted a clear detrimental influence on pine density. 
Author-produced version of the article published in Forest Ecology and Management, 2012, 282, 70-77.

Original publication available at http://www.sciencedirect.com/

doi : 10.1016/j.foreco.2012.06.043

Influence of treatments on soil surface conditions

273 Treatments and time strongly influenced soil surface conditions (Table 4).

274 Table 4

275 As expected, bare soil cover was higher in the scarification treatments (single or double) and

276 in the high-intensity controlled fire treatment than in the other treatments (Fig. 3). It strongly

277 decreased with time for all the sites, falling in three years from $24 \%$ to $5 \%$ in Barbentane (all

278 treatment included), from $10 \%$ to $4 \%$ in Saint-Cannat and from $62 \%$ to $16 \%$ in Vaison. The

279 decrease was less pronounced in the following years, but after 6 years $(9$ years for Saint280 Cannat) soil cover was less than $3 \%$ in all sites.

281 In contrast to bare soil cover, herb cover sharply increased in the years following treatment 282 application at all the sites. However, the increase was moderate from 3 years to 9 years in 283 Saint-Cannat (from 29\% to 33\%) and then fell to 7\%, whereas it was more pronounced in 284 Barbentane and Vaison, reaching respective mean values of $43 \%$ and $51 \%$. Scarification 285 treatments proved more favourable to herb cover development than the chopping and the 286 control treatments for Vaison and Saint-Cannat, whereas only the high-intensity controlled 287 fire treatment constantly reduced herb cover in Barbentane (29\% vs. $46 \%$ for the other 288 treatments).

289 Shrub cover gradually increased with time in all sites and for all treatments except for the 290 control treatment, where the increase was null or moderate. Shrub cover was higher in Saint291 Cannat (69\% at 9 years) than in Barbentane (35\% at 6 years) and Vaison (45\% at 6 years), 292 related to a weaker herb development as seen above. Chopping in Saint-Cannat and Vaison and high-intensity controlled fire in Barbentane were the treatments most favourable to shrub development. In contrast, scarification and low-intensity controlled fire were less favourable to shrub cover (see also Table 4).

Figure 3 
Author-produced version of the article published in Forest Ecology and Management, 2012, 282, 70-77.

Original publication available at http://www.sciencedirect.com/

doi : $10.1016 /$ j.foreco.2012.06.043

\section{$305 \quad$ Seedling dimensions}

306

307 Six years after the end of treatments, height was greater in the treatments with scarification

308 than in the other treatments in Barbentane and Vaison (Fig. 4). This positive effect of

309 scarification was still noted after 16 years in Saint-Cannat. We recorded similar results when

310 examining seedling mean stem diameter (data not shown).

311

312 Figure 4 
Author-produced version of the article published in Forest Ecology and Management, 2012, 282, 70-77. Original publication available at http://www.sciencedirect.com/

doi : 10.1016/j.foreco.2012.06.043

\section{Discussion}

$\underline{\text { Seedling density }}$

There are now a considerable number of studies on Aleppo pine post-fire regeneration (e.g. Arianoutsou and Ne'eman, 2000; Nathan and Ne'eman, 2004; Daskalakou and Thanos, 2010), but to our knowledge this is the first one that focuses on pine regeneration in fire-free conditions using long-term permanent field experiments. Mean pine densities found in this study a few years after treatment application (i.e., 1.06, 0.70 and 0.57 pines $/ \mathrm{m}^{2}$ for the three sites at 6-9 years) were comparable to those usually recorded in post-fire conditions. For instance, $1.24 \mathrm{pines} / \mathrm{m}^{2}$ were reported by Pausas et al. (2004a) in eastern Spain 8-9 years after fires, $1.00 \mathrm{pines} / \mathrm{m}^{2}$ in 8 -year-old post-fire woodlands in NE Spain (Papió, 1994 reported in Pausas et al., 2004a) and 0.3-0.5 pines $/ \mathrm{m}^{2}$ by Trabaud et al. (1985) in SE France. However, variations in densities recorded among our different treatments and sites (min. 0.05 to max. 2.33 pines $/ \mathrm{m}^{2}$ ) were far narrower than those reported in post-fire studies; e.g., Pausas et al. 2004a recorded variations from 0.006 to $20.4 \mathrm{pines} / \mathrm{m}^{2}$ and Tsitoni (1997) from 0.3 to 17 pines $/ \mathrm{m}^{2}$. Natural regeneration in fire-free conditions was in fact subject to less variability of the abiotic and biotic factors; in particular, seed rain was more controlled. Seed source was assured in our experiments by mature trees only, which occurred in similar proportions in the different sites (basal areas $9.5-12 \mathrm{~m}^{2} / \mathrm{ha}$ ). By contrast, in post-fire conditions, seed rain was largely dependent on fire conditions and stand characteristics. The release, after a fire event, of large aerial seed bank canopies of dense mature pine stands may lead, in conjunction with favourable climatic conditions, to the establishment of a "single massive wave" of seedlings during the first post-fire rainy season (Daskalakou and Thanos, 2004, 2010). By contrast, seed rain can be greatly reduced in young and sparse stands, thus severely limiting pine recruitment. This process explains the much higher fluctuations of densities recorded in post-fire studies than in our less variable conditions. It also explains why our pine densities peaked later (2-3 years) than in post-fire conditions where densities usually peaked in the first year following the fire (e.g. Daskalakou and Thanos, 2010). 
Author-produced version of the article published in Forest Ecology and Management, 2012, 282, 70-77.

Original publication available at http://www.sciencedirect.com/

doi : 10.1016/j.foreco.2012.06.043

$\underline{\text { Influence of treatments }}$

This study confirmed the influence of site preparation treatments on pine establishment, a finding that was previously established in one site (Barbentane) over a shorter period (3 years) (Prévosto and Ripert, 2008). Chopping followed by a single scarification (i.e. scarification in one direction) clearly appeared as the most favourable treatment in all three sites. Aleppo pines, like other pines species of temperate or boreal areas, require substantial disturbance of the forest floor to become successfully established (e.g. Beland et al., 2000; Nilsson et al., 2006; Wiensczyk et al., 2011). Scarification was associated with greater bare soil abundance and a temporal reduction of the herb cover, a factor that was clearly favourable to pine recruitment for all three sites. However, the presence of slash before the treatment application, tested in two sites, played either a positive (Barbentane) or negative (Vaison) role on pine density. The role of slash in pine recruitment is imperfectly known and diverse. Slash can exert a positive influence on pine regeneration by reducing soil temperature (Devine and Harrington, 2007) (although this advantage can shift to a disadvantage in colder areas), by increasing the number of cones offering an additional seed source, by improving soil moisture and by curbing vegetation competition (Johansson et al., 2006). Slash can also act as nurse objects that can improve microclimatic conditions and enhance pine seedling recruitment (Castro et al., 2011). Conversely, heavy slash loads can reduce the effectiveness of scarification (Landhäusser, 2009), create an unfavourable fluffy soil layer and possibly enhance release of autotoxic compounds (Fernandez et al., 2008). In the Barbentane site, the positive effect of slash can be explained by limitation of herb cover (20\% cover after 3 years instead of $32 \%$ without slash) as herb cover was clearly detrimental to pine establishment. In Vaison, explanations for the positive effect of slash removal were, however, less easy to find, although soil cover was slightly increased in the first year following this operation $(79 \% v s$. $63 \%)$.

373 Surprisingly, chopping followed by a double scarification with slash presence was less 374 (Barbentane) or no more (Vaison) favourable than a single scarification with slash. The 375 possible positive effect linked to cones in the slash could have been suppressed by a deeper burial of the cones by more intense scarification. Also, double scarification was of less benefit to shrub development, which in turn could influence seedling survival positively. In the harsh abiotic conditions prevailing in Barbentane, the outcome of seedling-shrub interactions were likely to result in facilitation due to attenuation of extreme temperature fluctuations and 
Author-produced version of the article published in Forest Ecology and Management, 2012, 282, 70-77.

Original publication available at http://www.sciencedirect.com/

doi : 10.1016/j.foreco.2012.06.043

excessive solar radiation on young pine seedling developing beneath shrub cover (Castro et al., 2002; Valladares et al., 2005)

The controlled fire treatments showed a contrasting effect on pine recruitment depending on the presence or absence of slash. The low-intensity fire in the absence of slash produced less bare soil, particularly in Saint-Cannat, and favoured herb layer development; these two factors being unfavourable to pine regeneration. The herb layer was dominated by the grass B. retusum, a rhizomatous perennial plant that is very competitive for water (Clary et al., 2004) and can successfully compete with pine seedlings (Pausas et al., 2003, Maestre et al., 2004). By contrast, the intense fire observed in the presence of slash was able to damage the root system of this plant and also reduce soil seed banks of herbaceous species. Reduction of the competiting herb layer thus resulted in enhanced pine recruitment. Controlled burning is usually restricted to fire prevention in the European Mediterranean area, but this study showed that if applied to reach a sufficient fire intensity, this method can be a valuable tool for stand regeneration. Besides, our results on the effect of controlled fire on pine regeneration are perfectly in line with studies performed in northern areas (e.g. Tellier et al., 1995; Hille and den Ouden, 2004; Hancock et al., 2009), these studies also emphasising the correlation between fire intensity and regeneration success.

Chopping in our study is, with low-intensity controlled fire, an inappropriate treatment for forest regeneration. Disturbances generated by this treatment did not produce enough bare soil and also, by removing only the aerial part of the ground vegetation, it did not prevent a relatively fast redevelopment of the competing herb layer.

Soil scarification clearly has a positive effect on seedling growth even after 16 years (site of Saint-Cannat). This result has been obtained with other pine species in northern areas (e.g. Bedford and Sutton, 2000; Mattsson and Bergsten, 2003; Landhäuser, 2009), but not in Aleppo pine forests. Better growth after scarification could be explained by improved nutrient and water status of the seedlings (Wetzel and Burgess, 2001) rather than by competition limitation. Growth amelioration was not recorded in the high-intensity controlled fire, although this treatment more severely limited the development of the competitive grass layer. The fact that double scarification was less favourable than single scarification has no straightforward explanation. More intense scarification could lead to a fluffy soil structure enriched with rocks and gravel and could therefore decrease soil water capacity. However, further studies are needed to assess more clearly the impact of scarification treatments on soil properties and resource availability for the plant in Mediterranean regions. 
Author-produced version of the article published in Forest Ecology and Management, 2012, 282, 70-77. Original publication available at http://www.sciencedirect.com/

doi : 10.1016/j.foreco.2012.06.043

$\underline{\text { Conclusion }}$

Aleppo pine recruitment has been almost exclusively studied after wildfires, whereas renewal of ageing stands in fire-free conditions has been largely ignored. In productive areas with a strong silvicultural focus, there is a need to develop techniques of natural regeneration that provide high seedling densities to produce wood for the lumber and pulp industry (Béland et al., 2000; Landhausser, 2009). In less productive areas, where different objectives are preferred (e.g. conservation, recreation), pine regeneration can still be needed to maintain pine in pure or in mixed stands. This study confirms that, as for other northern pine species, soil surface disturbance is the major driver for natural pine seedling establishment and therefore that site preparation treatments matter (e.g., see reviews by Balandier et al., 2006 and Wiensczyk et al., 2011). In particular, treatments are essential to reduce herb competition (at least temporarily) and allow pine recruitment.

Treatments such as chopping alone or controlled fire of low intensity are of low efficiency, as they do not favour pine establishment and do not reduce ground vegetation competition significantly. By contrast, chopping followed by moderate scarification clearly enhances pine installation and growth in all sites conditions. Scarification does not need to be very intense, and can even be detrimental to pine regeneration. Whether slash should be left or removed before treatments is debatable, as different results were obtained according to site conditions. This point requires further study to elucidate the influence of slash on abiotic and biotic micro-factors. Controlled fire of high intensity is to our knowledge not used in southern European pine forests as a tool for regeneration. This method merits further attention, as it opens a larger time-window for recruitment than the other treatments by increasing bare soil cover and by reducing competition on a long-term basis. 
Author-produced version of the article published in Forest Ecology and Management, 2012, 282, 70-77.

Original publication available at http://www.sciencedirect.com/

doi : 10.1016/j.foreco.2012.06.043

\section{Acknowledgements}

This study was funded by the Région Provence-Alpes-Côte d'Azur and the French Ministry of Agriculture (MAAPRAT -DRAAF PACA). The site of Barbentane was also funded by the French Ministry of Ecology (MEDDTL-DEB).

R Estève, A. N'Diaye, W. Martin, J.-L. Lopez provided helpful assistance for data collection in the field. The authors also thank the owner of the forest "Les Barons" and the communes of Barbentane and Vaison-la-Romaine for authorising forest trials and measurements on their properties.

\section{References}

Acácio, V., Holmgren, M., Jansen, P.A., Schrotter, O., 2007. Multiple recruitment limitation causes arrested succession in Mediterranean cork oak systems. Ecosystems 10, 1220-1230.

Arianoutsou, M., Ne'eman, G., 2000. Post-fire regeneration of natural Pinus halepensis forests in the east Mediterranean basin. In: Ne'eman, G., Trabaud, L. (Eds.), Ecology, Biogeography and Management of Pinus halepensis and P. brutia Forest Ecosystems in the Mediterranean Basin. Blackhuys Publishers, Leiden, pp. 269-289.

Balandier, P., Collet, C., Miller, J.H., Reynolds, P.E., Zedaker, S.M., 2006. Designing forest vegetation management strategies based on the mechanisms and dynamics of crop tree competition by neighbouring vegetation. Forestry 79, 3-27.

Baraza, E., Zamora, R., Hódar, J.A., 2006. Conditional outcomes in plant-herbivore interactions: neighbours matter. Oikos 133,148-156.

Barbéro, M., Loisel, R., Quézel, P., Richardson, D.M., Romane, F., 1998. Pines of the Mediterranean Basin. Ecology and Biogeography of Pinus, Richardson D.M. (ed). Cambridge University Press, Cambridge, UK.

Bedford, L., Sutton, R.F., 2000. Site preparation for establishing lodgepole pine in the subboreal spruce zone of interior British Columbia: the Bednesti trial, 10-year results. For Ecol. Manage. 126, 227-238. 
Author-produced version of the article published in Forest Ecology and Management, 2012, 282, 70-77.

Original publication available at http://www.sciencedirect.com/

doi : 10.1016/j.foreco.2012.06.043

482

483

484

485

486

487

488

489

490

491

492

493

494

495

496

497

498

499

500

501

502

503

504

505

506

Beland, M., Agestam, E., Ekö, P.-M., Gemmel, P., Nilsson, U., 2000. Scarification and seedfall affects natural regeneration of Scots pine under two shelterwood densities and a clear-cut in southern Sweden. Scand. J. For. Res. 15, 247-255.

Castro, J., Zamora, R., Hódar, J.A., Gómez, J.M., 2002. Use of shrubs as nurse plants: a new technique for reforestation in Mediterranean mountains. Restor. Ecol. 10, 297-305.

Castro, J., Zamora, R., Hódar, J.A., Gómez, J.M., 2004. Seedling establishment of a boreal tree species (Pinus sylvestris) at its southernmost distribution limit: consequences of being in a marginal Mediterranean habitat. J. Ecol. 92, 266-277.

Castro, J., Allen, C.D., Molina-Morales, M., Marañón-Jiménez, S., Sánchez-Miranda, Á., Zamora, R., 2011. Salvage jogging versus the use of burnt wood as nurse object to promote post-fire tree seedling establishment. Restor. Ecol. 19, 537-544.

Clary, J., Savé, R., Biel C., De Herralde, F., 2004. Water relations in competitive interactions of Mediterranean grasses and shrubs. Ann. Appl. Biol. 144, 149-155.

Daskalakou, E., Thanos, C.A., 1996. Aleppo pine (Pinus halepensis) postfire regeneration: the role of canopy and soil seed banks. Int. J. Wild. Fire 6, 59-66.

Daskalakou, E., Thanos, C.A., 2004. Postfire regeneration of Aleppo pine-the temporal pattern of seedling recruitment. Plant Ecol. 171, 81-89.

Daskalakou, E., Thanos, C.A., 2010. Postfire seedlings dynamics and performance in Pinus halepensis Mill. Populations. Acta Oecol. 36, 446-453.

Devine,W.D., Harrington, C.A., 2007. Influence of harvest residues and vegetation on microsite soil and air temperatures in a young conifer plantation. Agr For Meteor. 145:125138.

Fernandez, C., Voiriot, S., Mévy, J-P., Vila, B., Ormeño, E., Dupouyet, S., Bousquet-Mélou, A., 2008. Regeneration failure of Pinus halepensis Mill.: the role of autotoxicity and some abiotic environmental parameters. For. Ecol. Manage. 255, 2928-2936. 
Author-produced version of the article published in Forest Ecology and Management, 2012, 282, 70-77.

Original publication available at http://www.sciencedirect.com/

doi : 10.1016/j.foreco.2012.06.043

516 Hille, M., den Ouden, J., 2004. Improved recruitment and early growth of Scots pine (Pinus sylvestris L.) seedlings after fire and soil scarification. Eur. J. For. Res. 123, 213-218.

Hancock, M.H., Summers R.W., Amphlett, A., Willi, J., 2009. Testing prescribed fire as a tool to promote Scots pine Pinus sylvestris regeneration. Eur. J. For. Res. 128, 319-333.

Johansson,K., Orlander,G., Nilsson,U., 2006. Effects of mulching and insecticides on establishment and growth of Norway spruce. Can. J. For. Res. 36:2377-2385.

Landhäusser, S.M., 2009. Impact of slash removal, drag scarification, and mounding on lodgepole pine cone distribution and seedling regeneration after cut-to-length harvesting on high elevation sites. For. Ecol. Manage. 258, 43-49.

Maestre, F.T., Cortina, J., Bautista, S., 2004. Mechanisms underlying the interaction between

Pinus halepensis and the native late-successional shrub Pistacia lentiscus in a semi-arid plantation. Ecography 27, 776-786.

Mattson, S., Bergsten, U., 2003. Pinus contorta in northern Sweden as affected by soil scarification. New For. 26, 217-231.

Mendoza, I., Gómez-Aparicio, L., Zamora, R., Matias, L., 2009. Recruitment limitation of forest communities in a degraded Mediterranean landscape. J. Veg. Sci. 20, 367-376.

Nathan, R., Ne'eman, G., 2004. Spatiotemporal dynamics of recruitment in Aleppo pine (Pinus halepensis Miller) Plant Ecol. 171, 123-137.

Ne'eman, G., Goubitz, S., Nathan, R., 2004. Reproductive traits of Pinus halepensis in the 543 light of fire- a critical review. Plant Ecol. 171, 69-79.

Nilsson, U., Örlander, G., Karlsson, M., 2006. Establishing mixed forests in Sweden by 
Author-produced version of the article published in Forest Ecology and Management, 2012, 282, 70-77.

Original publication available at http://www.sciencedirect.com/

doi : 10.1016/j.foreco.2012.06.043

549 Papió, C., 1994. Ecologia del foc I regeneració en garrigues i pinedes mediterrànies. Institut 550 d'Estudis Catalans, Barcelona.

Pausas, J.G., Ribeiro, E., Vallejo, R., 2004a. Post-fire regeneration variability of Pinus halepensis in the eastern Iberian Peninsula. For. Ecol. Manage. 203, 251-259.

Pausas, J.G., Bladé, C., Valdecantos, A., Seva, J.P., Fuentes, D., Alloza, J.A., Milagrosa, A., Bautista, S., Cortina, J., Vallejo, R., 2004b. Pine and oaks in the restoration of Mediterranean landscapes of Spain: New perspectives for an old practice - a review. Plant Ecol. 171, 209220.

Pausas, J.G., Ouadah, N., Ferran, T., Gimeno, T., Vallejo, R., 2003. Fire severity and seedling establishment in Pinus halepensis woodlands, eastern Iberian Peninsula. Plant Ecol. 169:205213.

Prévosto B., Ripert C., 2008. Regeneration of Pinus halepensis stands after partial cutting in southern France: impacts of different ground vegetation, soil and logging flash treatments. For. Ecol. Manage. 256, 2058-2064.

Pulido, F.J., Diaz, M., de Trucios, S.J.H., 2001. Size structure and regeneration of Spanish holm oak Quercus ilex forests and dehesas: effects of agroforestry use on their long-term sustainability. For. Ecol. Manage. 146, 1-13.

Richardson, D., 2000. Mediterranean pines as invaders in the Southern Hemisphere. In: and P. brutia Ecosystems in the Mediterranean Basin. Backhuys Publishers, Leiden, pp. 131142.

Rodríguez-García, E., Juez, L., Bravo, F., 2010. Environmental influences on post-harvest natural regeneration of Pinus pinaster Ait. in Mediterranean forest stands submitted to the seed-tree selection method. Eur. J. Forest Res., 129:1119-1128.

Siegel, S., Castellan, N.J., 1988. Non parametric statistics for the behavioural sciences. 
Author-produced version of the article published in Forest Ecology and Management, 2012, 282, 70-77.

Original publication available at http://www.sciencedirect.com/

doi : 10.1016/j.foreco.2012.06.043

Smit, C., Diaz, M., Jansen, P., 2009. Establishment limitation of holm oak (Quercus ilex subsp. ballota (Desf.) Samp.) in a Mediterranean savanna-forest ecosystem. Ann For. Sci. 66, 511-511p7.

Scarascia-Mugnozza, G., Oswald, H., Piussi, P., Radoglou, K., 2000. Forests of the Mediterranean region: gaps in knowledge and research needs. For. Ecol. Manage. 132, 97109.

Spiecker, H., 2003. Silvicultural management in maintaining biodiversity and resistance of forests in Europe-temperate zone. J. Env. Manage. 67, 55-65.

Tellier, R., Duchesne, L.C., Ruel, J.-C., McAlpine, R.S., 1995. Effets du brûlage dirigé et du scarifiage sur l'établissement des semis et sur leur interaction avec la végétation concurrente.For Chron. 71, 621-626.

Trabaud, L., Michels, C., Grosman, J., 1985. Recovery of burnt Pinus halepensis Mill forests.

Tsitsoni, T., 1997. Conditions determining natural regeneration after wildfires in the Pinus 603 halepensis (Miller, 1768) forests of Kassandra Peninsula (North Greece). For. Ecol. Manage. 92, 199-208.

605

Valladares, F., Dobarro, I., Sánchez- Gómez, D., Pearcy, R.W., 2005. Photoinhibition and drought in Mediterranean saplings: scaling effects and interactions in sun and shade phenotypes. J. Exp. Bot. 56, 483-494.

Wetzel, S., Burgess, D., 2001. Understorey environment and vegetation response after partial cutting and site preparation in Pinus strobus L. stands. For. Ecol. Manage. 151, 43-59.

613 Wiensczyk, A., Swift, K., Morneault, A., Thiffault, N., Szuba, K., Bell, W., 2011. An 614 overview of the efficacy of vegetation management alternatives for conifer regeneration in boreal forests. For. Chron. 87, 175-200. 
Author-produced version of the article published in Forest Ecology and Management, 2012, 282, 70-77. Original publication available at http://www.sciencedirect.com/ doi : 10.1016/j.foreco.2012.06.043

617 Zavala, M.A., Espelta, J.M., Retana, J., 2000. Constraints and trade-offs in Mediterranean 618 plant communities: the case of Holm oak-Aleppo pine forests. Bot. Rev. 66, 119-149. 
Author-produced version of the article published in Forest Ecology and Management, 2012, 282, 70-77.

Original publication available at http://www.sciencedirect.com/

doi : 10.1016/j.foreco.2012.06.043

619 Table 1. Main ecological factors and stand characteristics (before and after the regeneration

620 cut) for the three sites

$621 \mathrm{~A}=$ altitude, $\mathrm{P}=$ mean annual rainfall, $\mathrm{T}=$ mean annual temperature, $\mathrm{G}=$ pine basal area, $\mathrm{N}=$

622 pine density, Age = mean stand age, $\mathrm{Ho}=$ mean pine dominant height.

\begin{tabular}{|c|c|c|c|c|c|c|c|c|c|c|}
\hline \multicolumn{4}{|c|}{ Site characteristics } & \multicolumn{2}{|c|}{$\begin{array}{l}\text { Initial stand } \\
\text { (before cut) }\end{array}$} & \multirow{2}{*}{$\begin{array}{l}\text { Date of } \\
\text { cut } \\
\text { Year }\end{array}$} & \multicolumn{2}{|c|}{$\begin{array}{l}\text { Final stand } \\
\text { (after cut) }\end{array}$} & \multirow[b]{2}{*}{$\begin{array}{l}\mathrm{N} \\
(\mathrm{nb} / \mathrm{ha})\end{array}$} & \multirow[b]{2}{*}{$\begin{array}{l}\text { Ho } \\
\text { (m) }\end{array}$} \\
\hline $\begin{array}{l}\text { A } \\
(\mathrm{m})\end{array}$ & $\begin{array}{l}\mathrm{P} \\
(\mathrm{mm})\end{array}$ & $\begin{array}{l}\mathrm{T} \\
\left({ }^{\circ} \mathrm{C}\right)\end{array}$ & Soil & $\begin{array}{l}\mathrm{G} \\
\left(\mathrm{m}^{2} / \mathrm{ha}\right)\end{array}$ & $\begin{array}{l}\mathrm{N} \\
\text { (nb/ha) }\end{array}$ & & $\begin{array}{l}\text { Age } \\
\text { (year) }\end{array}$ & $\begin{array}{l}\mathrm{G} \\
\left(\mathrm{m}^{2} / \mathrm{ha}\right)\end{array}$ & & \\
\hline 105 & 673 & 13.8 & $\begin{array}{l}\text { Superficial } \\
\text { calcareous } \\
\text { soil }\end{array}$ & 20 & 450 & 2003 & 90 & 12 & 180 & 13 \\
\hline 245 & 620 & 13.3 & $\begin{array}{l}\text { Calcareous } \\
\text { soil }\end{array}$ & 14 & 80 & 1991 & 90 & 10 & 60 & 15 \\
\hline 300 & 761 & 12.3 & $\begin{array}{l}\text { Deep } \\
\text { calcareous } \\
\text { soil }\end{array}$ & 18 & 150 & 2002 & 85 & 9 & 92 & 16 \\
\hline
\end{tabular}

623

624

625

626

627

628

629

630 
Author-produced version of the article published in Forest Ecology and Management, 2012, 282, 70-77. Original publication available at http://www.sciencedirect.com/

doi : 10.1016/j.foreco.2012.06.043

631 Table 2. Types of treatments tested in the three sites, surface used for treatment application

632 (plot size) and total number of subplots used each year for seedlings counting. Abbreviations

633 are: CONT: control, CHOP: chopping, SCA1: chopping + soil scarification in one direction,

634 SCA2: chopping + soil scarification in two directions; FIRE: controlled fire, _S0: no slash,

635 _S1: presence of slash prior to the treatment application.

636

637

638

\begin{tabular}{|c|c|c|c|c|c|c|c|c|c|}
\hline & CONT & CHOP_S1 & FIRE_S0 & FIRE_S1 & SCA1_S0 & SCA1_S1 & SCA2_S1 & $\begin{array}{l}\text { Plot } \\
\text { size } \\
\left(\mathrm{m}^{2}\right)\end{array}$ & $\begin{array}{l}\mathrm{Nb} \text { of } 1 \mathrm{~m}^{2} \\
\text { subplots } \\
\text { sampled/year }\end{array}$ \\
\hline Barbentane & $x$ & $x$ & $x$ & $x$ & $x$ & $x$ & $x$ & 200 & 400 \\
\hline Saint-Cannat & $x$ & $x$ & $x$ & & & $x$ & & 200 & 576 \\
\hline Vaison & $x$ & $x$ & & & $x$ & $x$ & $x$ & $\begin{array}{l}600- \\
2000\end{array}$ & 369 \\
\hline
\end{tabular}

639 
Author-produced version of the article published in Forest Ecology and Management, 2012, 282, 70-77. Original publication available at http://www.sciencedirect.com/

doi : 10.1016/j.foreco.2012.06.043

640 Table 3. Results of the generalised linear models: pine density as function of treatments, time

641 (in years) and soil surface conditions (in \%). Intercept values are not shown, P values are

642 coded: $* * *(\mathrm{P}<0.001), * *(0.001<\mathrm{P}<0.01), *(0.01<\mathrm{P}<0.05)$ and ns (not significant, $\mathrm{P}>0.05)$.

643 Treatments' abbreviations: see Table 2.

644

645

\begin{tabular}{llllllllll} 
& \multicolumn{3}{l}{ Barbentane } & \multicolumn{3}{l}{ Saint-Cannat } & \multicolumn{3}{l}{ Vaison } \\
\cline { 2 - 9 } Treatments & $\mathrm{df}$ & deviance & $\mathrm{P}$ & $\mathrm{df}$ & deviance & $\mathrm{P}$ & $\mathrm{P}$ & deviance & $\mathrm{P}$ \\
\cline { 2 - 9 } Time & 1 & 551.5 & $* * *$ & 3 & 892.3 & $* * *$ & 4 & 156.5 & $* * *$ \\
Herb cover & 1 & 36.1 & $* * *$ & 1 & 370.0 & $* * *$ & 1 & 4.8 & $*$ \\
Bare soil cover & 1 & 167.2 & $* * *$ & 1 & 31.6 & $* * *$ & 1 & 11.0 & $* * *$ \\
Shrub cover & 1 & 45.9 & $* * *$ & 1 & 2.1 & $\mathrm{~ns}$ & 1 & 2.2 & $\mathrm{~ns}$ \\
\end{tabular}

\begin{tabular}{lcclcccccl}
\hline & Estim. & SE & P & Estim. & SE & P & Estim. & SE & P \\
\cline { 2 - 8 } SCA1_S0 & 0.479 & 0.106 & $* * *$ & 1.065 & 0.089 & $* * *$ & 1.182 & 0.158 & $* * *$ \\
SCA1_S1 & 1.218 & 0.098 & $* * *$ & & & & 0.500 & 0.161 & $* *$ \\
FIRE_S0 & -0.022 & 0.112 & $\mathrm{~ns}$ & -0.756 & 0.104 & $* * *$ & & & \\
FIRE_S1 & 1.066 & 0.104 & $* * *$ & & & & & & \\
CONT_S0 & -0.895 & 0.128 & $* * *$ & -1.373 & 0.117 & $* * *$ & -2.500 & 0.533 & $* * *$ \\
SCA2_S1 & 0.791 & 0.102 & $* * *$ & & & & 0.443 & 0.162 & $* *$ \\
Time & -0.087 & 0.021 & $* * *$ & -0.123 & 0.007 & $* * *$ & 0.163 & 0.038 & $* * *$ \\
Herb cover & -0.018 & 0.001 & $* * *$ & -0.007 & 0.002 & $* * *$ & -0.007 & 0.002 & $* *$ \\
Bare soil cover & -0.015 & 0.002 & $* * *$ & 0.004 & 0.003 & $\mathrm{~ns}$ & 0.002 & 0.003 & $\mathrm{~ns}$ \\
Shrub cover & 0.002 & 0.002 & $\mathrm{~ns}$ & 0.002 & 0.001 & $\mathrm{~ns}$ & -0.005 & 0.002 & $*$ \\
\hline Deviance & 24.5 & & & 40.4 & & & 13.0 & & \\
explained (\%) & & & & & & & & & \\
\hline
\end{tabular}

64

647

648

649

650 
Author-produced version of the article published in Forest Ecology and Management, 2012, 282, 70-77. Original publication available at http://www.sciencedirect.com/

doi : 10.1016/j.foreco.2012.06.043

651 Table 4. Results of the generalised linear models: soil surface conditions as function of

652 treatments and time (in year). Intercept values not shown, $\mathrm{P}$ values are coded: $* * *(\mathrm{P}<0.001)$,

$653 * *(0.001<\mathrm{P}<0.01), *(0.01<\mathrm{P}<0.05)$ and ns (not significant, $\mathrm{P}>0.05)$. Treatments'

654 abbreviations: see Table 2 .

655

\begin{tabular}{|c|c|c|c|c|c|c|c|c|c|}
\hline \multirow[b]{2}{*}{$\begin{array}{l}\text { Deviance } \\
\left(\times 10^{3}\right)\end{array}$} & \multicolumn{3}{|c|}{ Barbentane } & \multicolumn{3}{|c|}{ Saint-Cannat } & \multicolumn{3}{|l|}{ Vaison } \\
\hline & $\begin{array}{l}\text { Herb } \\
\text { cover }\end{array}$ & $\begin{array}{l}\text { Soil } \\
\text { cover }\end{array}$ & $\begin{array}{l}\text { Shrub } \\
\text { cover }\end{array}$ & $\begin{array}{l}\text { Herb } \\
\text { cover }\end{array}$ & $\begin{array}{l}\text { Soil } \\
\text { cover }\end{array}$ & $\begin{array}{l}\text { Shrub } \\
\text { cover }\end{array}$ & $\begin{array}{l}\text { Herb } \\
\text { cover }\end{array}$ & $\begin{array}{l}\text { Soil } \\
\text { cover }\end{array}$ & $\begin{array}{l}\text { Shrub } \\
\text { cover }\end{array}$ \\
\hline Treatment & $\begin{array}{l}56.5 \\
(* * *)\end{array}$ & $\begin{array}{l}54.9 \\
(* * *)\end{array}$ & $\begin{array}{l}110.9 \\
(* * *)\end{array}$ & $\begin{array}{l}17.0 \\
(* * *)\end{array}$ & $\begin{array}{l}28.6 \\
(* * *)\end{array}$ & $\begin{array}{l}134.2 \\
(* * *)\end{array}$ & $\begin{array}{l}108.2 \\
(* * *)\end{array}$ & $\begin{array}{l}112.0 \\
(* * *)\end{array}$ & $\begin{array}{l}123.0 \\
(* * *)\end{array}$ \\
\hline Time & $\begin{array}{l}353.1 \\
(* * *)\end{array}$ & $\begin{array}{l}130.8 \\
(* * *)\end{array}$ & $\begin{array}{l}141.6 \\
(* * *)\end{array}$ & $\begin{array}{l}44.1 \\
(* * *)\end{array}$ & $\begin{array}{l}19.8 \\
(* * *)\end{array}$ & $\begin{array}{l}172.3 \\
(* * *)\end{array}$ & $\begin{array}{l}381.6 \\
(* * *)\end{array}$ & $\begin{array}{l}658.5 \\
(* * *)\end{array}$ & $\begin{array}{l}230.9 \\
(* * *)\end{array}$ \\
\hline Estimate & $\begin{array}{l}\text { Herb } \\
\text { cover }\end{array}$ & $\begin{array}{l}\text { Soil } \\
\text { cover }\end{array}$ & $\begin{array}{l}\text { Shrub } \\
\text { cover }\end{array}$ & $\begin{array}{l}\text { Herb } \\
\text { cover }\end{array}$ & $\begin{array}{l}\text { Soil } \\
\text { cover }\end{array}$ & $\begin{array}{l}\text { Shrub } \\
\text { cover }\end{array}$ & $\begin{array}{l}\text { Herb } \\
\text { cover }\end{array}$ & $\begin{array}{l}\text { Soil } \\
\text { cover }\end{array}$ & $\begin{array}{l}\text { Shrub } \\
\text { cover }\end{array}$ \\
\hline SCA1_S0 & $\begin{array}{l}2.38 \\
\text { (ns) }\end{array}$ & $\begin{array}{l}6.78 \\
(* * *)\end{array}$ & $\begin{array}{l}-0.13 \\
(\mathrm{~ns})\end{array}$ & $\begin{array}{l}4.47 \\
(* *)\end{array}$ & $\begin{array}{l}7.90 \\
(* * *)\end{array}$ & $\begin{array}{l}-13.09 \\
(* * *)\end{array}$ & $\begin{array}{l}14.39 \\
(* * *)\end{array}$ & $\begin{array}{l}18.56 \\
(* * *)\end{array}$ & $\begin{array}{l}-7.75 \\
(* * *)\end{array}$ \\
\hline SCA1_S1 & $\begin{array}{l}-5.01 \\
(* *)\end{array}$ & $\begin{array}{l}6.13 \\
(* * *)\end{array}$ & $\begin{array}{l}3.35 \\
(*)\end{array}$ & & & & $\begin{array}{l}11.23 \\
(* * *)\end{array}$ & $\begin{array}{l}13.62 \\
(* * *)\end{array}$ & $\begin{array}{l}-4.68 \\
(* *)\end{array}$ \\
\hline FIRE_S0 & $\begin{array}{l}1.65 \\
\text { (ns) }\end{array}$ & $\begin{array}{l}6.32 \\
(* * *)\end{array}$ & $\begin{array}{l}-1.49 \\
\text { (ns) }\end{array}$ & $\begin{array}{l}3.87 \\
(* *)\end{array}$ & $\begin{array}{l}1.53 \\
(*)\end{array}$ & $\begin{array}{l}-10.31 \\
(* * *)\end{array}$ & & & \\
\hline FIRE_S1 & $\begin{array}{l}-11.94 \\
(* * *)\end{array}$ & $\begin{array}{l}13.85 \\
(* * *)\end{array}$ & $\begin{array}{l}4.34 \\
(* *)\end{array}$ & & & & & & \\
\hline CONT_SO & $\begin{array}{l}-4.47 \\
(*)\end{array}$ & $\begin{array}{l}-1.57 \\
(\mathrm{~ns})\end{array}$ & $\begin{array}{l}17.60 \\
(* * *)\end{array}$ & $\begin{array}{l}-2.08 \\
\text { (ns) }\end{array}$ & $\begin{array}{l}-1.25 \\
(*)\end{array}$ & $\begin{array}{l}5.76 \\
(* * *)\end{array}$ & $\begin{array}{l}-20.27 \\
(* * *)\end{array}$ & $\begin{array}{l}5.16 \\
(*)\end{array}$ & $\begin{array}{l}20.46 \\
(* * *)\end{array}$ \\
\hline SCA2_S1 & $\begin{array}{l}0.72 \\
\text { (ns) }\end{array}$ & $\begin{array}{l}4.76 \\
(* * *)\end{array}$ & $\begin{array}{l}-4.36 \\
(* *)\end{array}$ & & & & $\begin{array}{l}4.91 \\
(* *)\end{array}$ & $\begin{array}{l}18.50 \\
(* * *)\end{array}$ & $\begin{array}{l}-6.66 \\
(* * *)\end{array}$ \\
\hline Time & $\begin{array}{l}6.93 \\
(* * *)\end{array}$ & $\begin{array}{l}-4.22 \\
(* * *)\end{array}$ & $\begin{array}{l}4.39 \\
(* * *)\end{array}$ & $\begin{array}{l}-0.75 \\
(* * *)\end{array}$ & $\begin{array}{l}-0.50 \\
(* * *)\end{array}$ & $\begin{array}{l}1.48 \\
(* *)\end{array}$ & $\begin{array}{l}7.78 \\
(* * *)\end{array}$ & $\begin{array}{l}-10.22 \\
(* * *)\end{array}$ & $\begin{array}{l}6.05 \\
(* * *)\end{array}$ \\
\hline $\begin{array}{l}\text { Deviance } \\
\text { explained } \\
(\%)\end{array}$ & 23.0 & 36.7 & 23.0 & 4.4 & 15.8 & 16.5 & 32.6 & 53.0 & 30.0 \\
\hline
\end{tabular}


Author-produced version of the article published in Forest Ecology and Management, 2012, 282, 70-77. Original publication available at http://www.sciencedirect.com/

doi : 10.1016/j.foreco.2012.06.043

\section{Figure captions}

658

659 Figure1. Location of the three sites in southern France

660

661 Figure 2. Changes in pine density (mean \pm SE) with time for the different treatments at the

662 three sites. Abbreviations are: CONT: control, CHOP: chopping, SCA1: chopping + soil

663 scarification in one direction, SCA2: chopping + soil scarification in two directions; FIRE:

664 controlled fire, S0: no slash, S1: presence of slash.

665

666 Figure 3. Changes in soil, herb and shrub covers (mean \pm SE) with time as a function of the

667 treatments for the three sites. Stars indicate significant differences between the treatments at

668 each year $(* P<0.05$; ** $P<0.01$, *** $P<0.001)$. See Fig.1 for treatment abbreviations.

669

670 Figure 4. Seedling height (mean \pm SE) as function of the treatments for the three sites. Height

671 was computed for treatments with at least 30 seedlings (otherwise data not shown). Letters

672 indicate statistical differences between the treatments. See Fig.1 for treatment abbreviations. 
Author-produced version of the article published in Forest Ecology and Management, 2012, 282, 70-77. Original publication available at http://www.sciencedirect.com/

doi : 10.1016/j.foreco.2012.06.043

673

674

675

676

677

678

679

680

681

682

683

684

685

686

687

688

689

690

691

692

693

694

695

696
Fig. 1

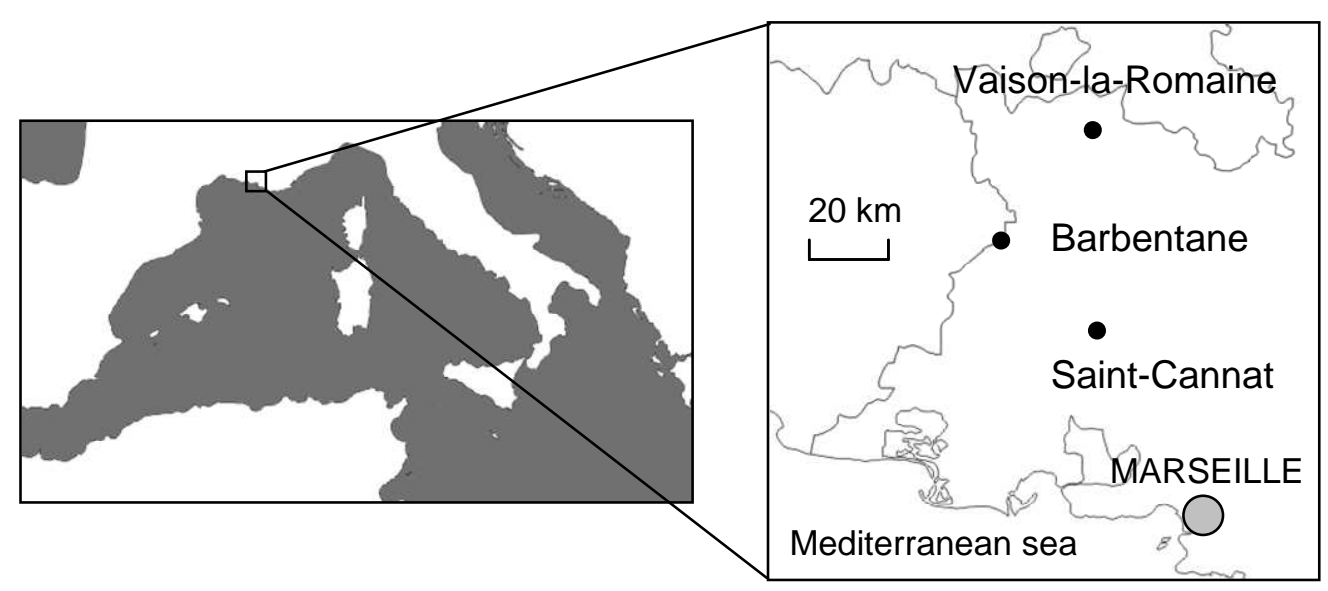


Author-produced version of the article published in Forest Ecology and Management, 2012, 282, 70-77. Original publication available at http://www.sciencedirect.com/

doi : 10.1016/j.foreco.2012.06.043

697

698

699

700

701

702

703

704

705

706

707

708

709

710

711

712

713

714

715

716

717

718

719

720

721

722

723

724

725

726

727

728

729

730

731

732

733

734

735

736

737

738

739

740

741

742

743

744

Fig. 2

Barbentane

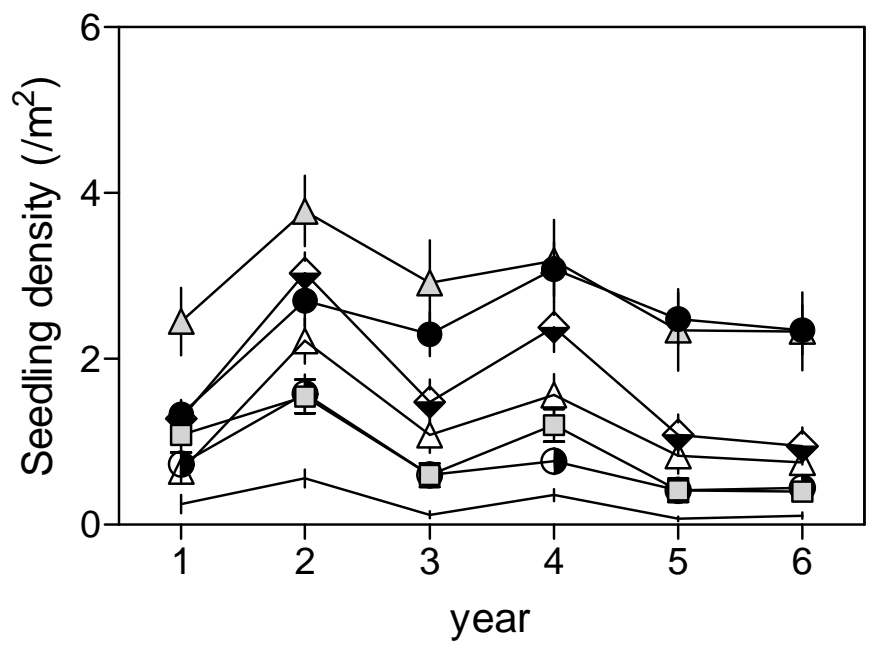

$\triangle$ SCA1_S0

$\triangle$ SCA1_S1

SCA2_S1

- FIRE SO

- - CHOP_S1

- FIRE_S1

- CONT
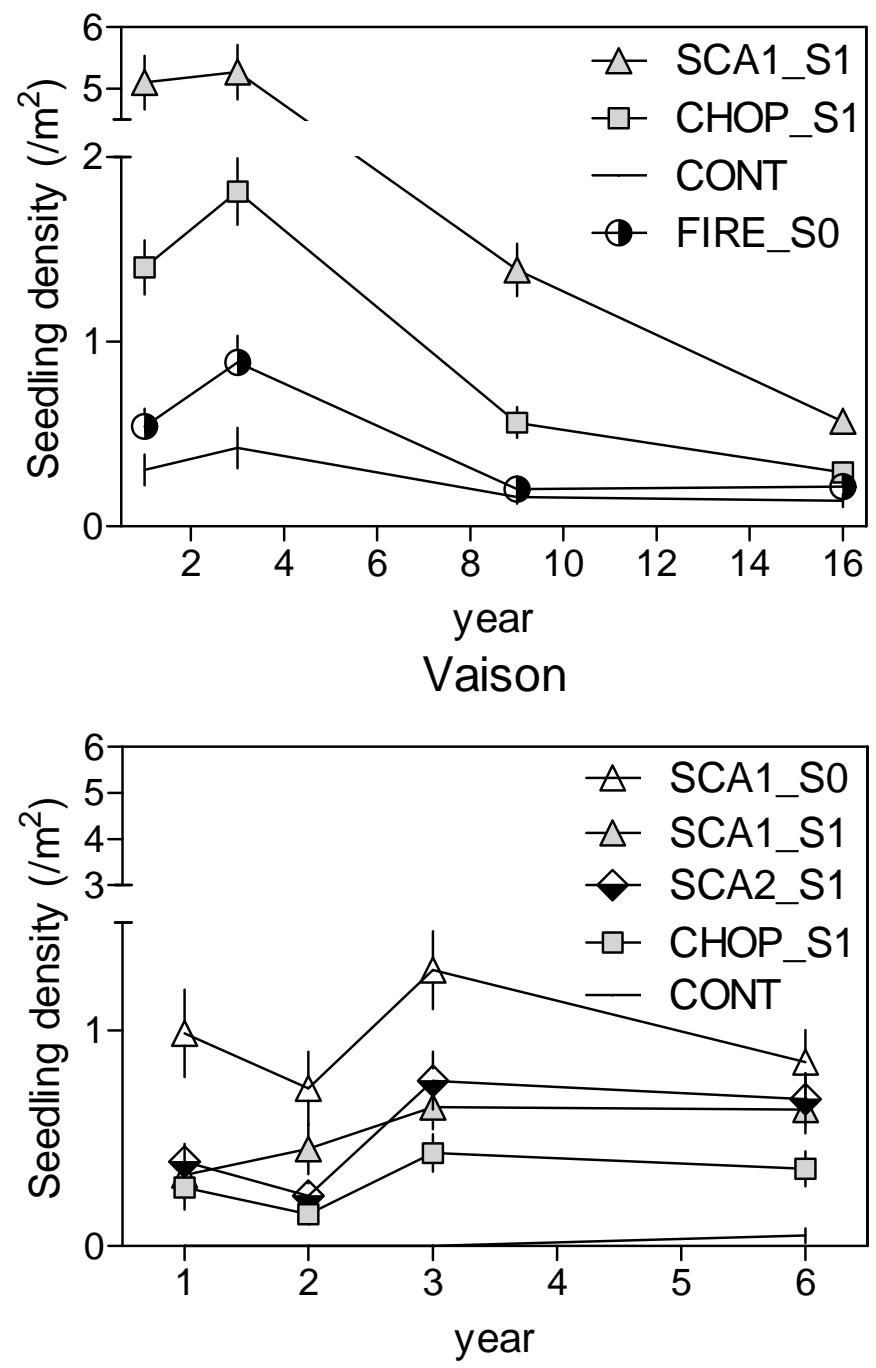
Author-produced version of the article published in Forest Ecology and Management, 2012, 282, 70-77. Original publication available at http://www.sciencedirect.com/

doi : 10.1016/j.foreco.2012.06.043

Fig. 3

Barbentane

749

750

751 응

752

753 음

754 熍

755

756

757

758

759

760 응 60

761

762 。

763

764

765

766

767

768

769

770 응

771 产 40

772

773 क 20

774

775

776

777

778

779

780

781

782

783

784

785

786

787

788
Saint-Cannat
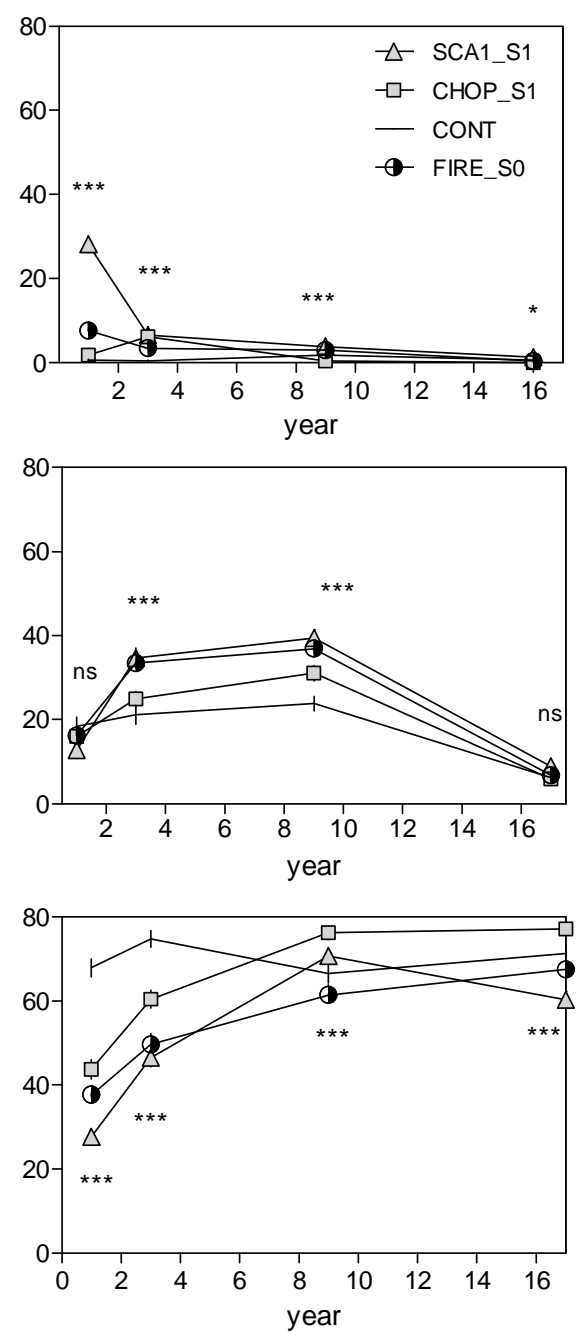

Vaison
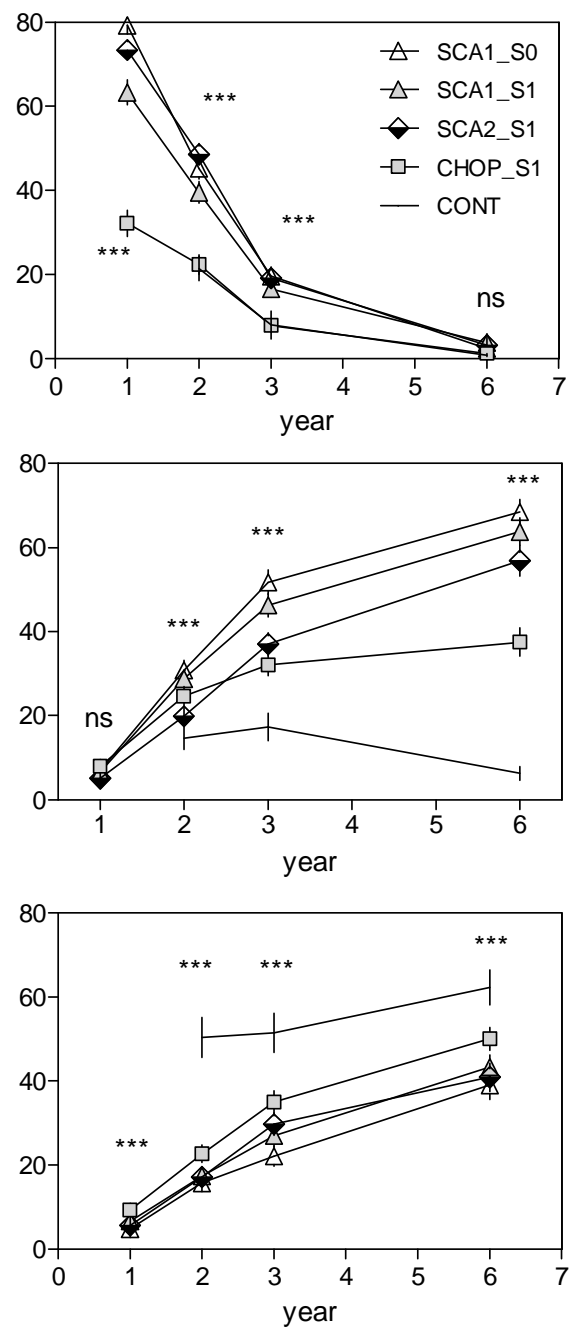

789 
Author-produced version of the article published in Forest Ecology and Management, 2012, 282, 70-77. Original publication available at http://www.sciencedirect.com/

doi : 10.1016/j.foreco.2012.06.043

790

791

792

Fig. 4

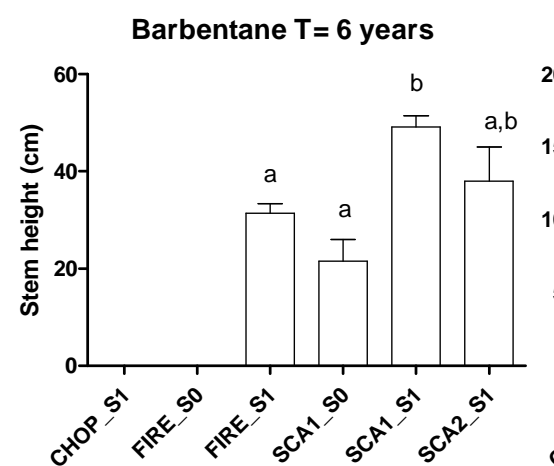

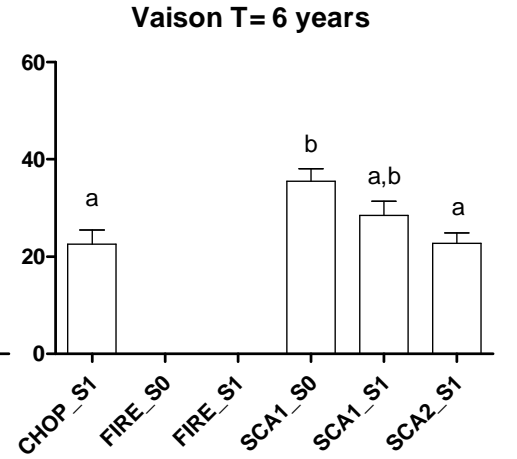

793

794

795

796

797

798

799

800

801

802

803

804

805

806

807

808

809

810

811

812

813

814

815

816

817

818

819

820

821

822

823

824

825

826

827

828 